\title{
SIFAT FISIK DAN ORGANOLEPTIK MIE DARI TEPUNG TALAS (Colocasia esculenta) DAN TERIGU DENGAN PENAMBAHAN SARI BAYAM MERAH (Amaranthus blitum)
}

\section{Physical and Organoleptic Properties of Noodle Made from Taro Root (Colocasia Esculenta) and Wheat Flour with the Addition of Red Spinach Juice (Amaranthus Blitum)}

\author{
Meiheski R. Rara ${ }^{1 *}$, Teltje Koapaha ${ }^{2}$ dan Dekie Rawung ${ }^{2)}$ \\ 1) Mahasiswa Program Studi Teknologi Pangan \\ ${ }^{2)}$ Dosen Program Studi Teknologi Pangan \\ Jurusan Teknologi Pertanian Universitas Sam Ratulangi Manado \\ Jl. Kampus UNSRAT Manado, 95115. \\ *e-mail: r2meiheski@gmail.com
}

\begin{abstract}
This study aims to evaluate the proportion of taro flour to produce the best noodles based on the physical characteristics and preferences by panelists. This study uses a completely randomized design with 4 treatments A (100\% wheat flour) as a control, B (80\% taro flour: $20 \%$ wheat flour), C (70\% taro flour: $30 \%$ wheat flour), D (60\% taro flour: $40 \%$ wheat flour). The parameters analyzed were water absorption, elasticity, cooking time, cooking loss, moisture content, antioxidant activity and acceptance level of the panelists. From the results of the research on testing the physical properties of taro noodles with water absorbency an average value of $90.40 \%$, elasticity obtained an average value of $15.87 \%$, cooking time obtained an average value of 210.67 seconds, cooking loss obtained value on average $21.37 \%$ and water content obtained an average value of $24.83 \%$. Meanwhile, the antioxidant activity of taro noodles is classified as weak, namely the IC50 value is $225.82 \mu \mathrm{g} / \mathrm{ml}$. For organoleptic tests, the average panelist gave likes value for color and neutral for smell, but they did not like the taste and texture of wet noodles made from taro flour with the addition of red spinach juice.
\end{abstract}

Keywords: Taro, red spinach, wet noodles

\section{PENDAHULUAN}

Mie merupakan salah satu produk pangan yang banyak diminati masyarakat Indonesia, mulai dari anak-anak sampai orang dewasa. Menurut Murniyati, dkk., (2010), konsumsi mie di Indonesia tercatat terbesar kedua di dunia setelah RRC. 
Volume impor gandum atau terigu sebagai bahan baku pembuatan mie terus meningkat. Berdasarkan data Asosiasi Tepung Terigu Indonesia (APTINDO) volume impor gandum Indonesia pada 2017 naik sekitar 9\% menjadi 11,48 juta ton dari tahun sebelumnya dengan nilai US\$ 2,65 miliar

Upaya untuk mengurangi impor terigu dapat dilakukan dengan memberdayakan pangan lokal termasuk talas. Talas (Colocasia esculenta) termasuk sumber penghasil karbohidrat non beras dari golongan umbi-umbian, dengan kandungan karbohidrat yang tinggi, terutama pati yaitu $80 \%$ (Rahmawati, dkk., 2012). Dengan kandungan pati yang tinggi, maka talas dapat dimanfaatkan sebagai pengganti sebagian dari fungsi terigu dalam pembuatan produk pangan. Untuk mempermudah penggunaan dan memperpanjang umur simpan, umbi talas diolah menjadi tepung talas. Tepung talas yang tergolong halus dan mudah dicerna, berguna untuk pembuatan kue kering, kue basah, roti dan mie (Suhaeni, 2007). Beberapa penelitian telah dilakukan menggunakan tepung talas seperti mie basah, mie instan, roti (Permatasari, dkk.,2009; Gumilang, dkk., 2015; Pratiwi, dkk.,2017). Namun, tepung talas tidak mengandung gluten yang membuat mie elastis, sehingga pada pembuatan produk seperti mie, perlu adanya penambahan bahan yang mengandung gluten seperti tepung terigu.

Bayam merah manado (Amaranthus blitum) dapat dimanfaatkan sebagai produk pangan fungsional karena memiliki kandungan antioksidan yaitu betalain, karotenoid, vitamin $\mathrm{C}$, flavonoid dan polifenol (Wiyasihati dan Kristanti, 2016). Antioksidan merupakan senyawa yang berfungsi mengikat pembentukan radikal bebas. Radikal bebas dalam tubuh dapat menyebabkan penyakit degeneratif seperti serangan jantung, kanker, katarak, menurunnya fungsi ginjal, aterosklerosis, osteoporosis dan lain-lain. Selain itu, penambahan bayam merah pada produk pangan akan memberikan warna yang menarik.

Berdasarkan latar belakang tersebut, maka dilakukan penelitian mengenai pengembangan produk mie basah dari tepung talas untuk mengurangi ketergatungan terhadap tepung terigu dan potensi mie sebagai pangan fungsional dengan parameter uji karakteristik fisik, aktivitas antioksidan dan uji organoleptik.

\section{METODE PENELITIAN}

\section{Tempat dan Waktu Penelitian}

Penelitian ini dilakukan di Laboratorium Ilmu Pangan, Laboratorium Paska Panen Jurusan Teknologi Pertanian, Fakultas Pertanian dan Laboratorium Analisis Ilmu Farmasi Universitas Sam Ratulangi sejak bulan Oktober 2018 sampai dengan bulan April 2019.

\section{Bahan dan Alat}

Bahan yang digunakan dalam penelitian ini adalah umbi talas yang diolah menjadi tepung talas menggunakan metode penggilingan kering, sari bayam merah yang diperoleh dari Sulawesi utara dan tepung terigu.

Alat yang digunakan pada penelitian ini terdiri dari cabinet dryer, oven listrik, timbangan, blender, slicer, kompor, roll press.

\section{Rancangan Penelitian}

Penelitian ini dilakukan dengan menggunakan Rancangan Acak Lengkap (RAL) dengan masing-masing perlakuan ditambahkan sari bayam merah sebanyak $40 \mathrm{ml}$ yang terdiri dari 4 perlakuan dengan proporsi tepung talas dan terigu yang berbeda berbeda:
A: $100 \%$ Tepung Terigu (kontrol)
B: $80 \%$ Tepung Talas $+20 \%$ Tepung Terigu 


\section{C: $70 \%$ Tepung Talas $+30 \%$ Tepung Terigu \\ D: $60 \%$ Tepung Talas $+40 \%$ Tepung Terigu}

Masing-masing perlakuan diulang sebanyak 3 kali. Data yang diperoleh diolah dengan Analisis Sidik Ragam (ANOVA).

\section{Prosedur penelitian}

Bahan baku umbi talas dicuci dan dikupas, lalu diiris dan direndam dalam larutan $\mathrm{NaCl}$ selama 1 jam, lalu dicuci kembali dengan air, kemudian dikeringkan menggunakan oven bersuhu \pm 70 dengan cabinet drying selama 9 jam, selanjutnya diayak dengan pengayakan 80 mesh untuk menghasilkan tepung yang halus.

Pembuatan sari bayam merah dilakukan dengan cara daun bayam dicuci bersih, lalu diblancing selama 2 menit, kemudian ditiriskan dan di blender, lalu disaring untuk diambil sarinya.

Pembutan mie talas dilakukan dengan cara mencampur tepung talas dan terigu sesuai perlakuan sebanyak 100 gram, lalu campurkan telur 20 gram, garam 2 gram, CMC 2 gram. Tambahkan sari bayam merah $40 \mathrm{ml}$ pada masingmasing perlakuan. Campurkan semua bahan sampai homogen dan aduk sampai adonan kalis. Adonan dibagi menjadi beberapa bagian kemudian bentuk lembaran menggunakan alat penipis adonan dengan ketebalan $2 \mathrm{~mm}$, kemudian digiling/dicetak menggunakan gilingan mie. Selanjutnya mie direbus pada suhu $100^{\circ} \mathrm{C}$ selama 30 detik. Diangkat lalu ditiriskan.

\section{Daya Serap Air Metode AACC 66-507,} (Kang, dkk., 2017)

Sampel ditimbang sebanyak $10 \mathrm{~g}$ kemudian direbus dalam air mendidih sebanyak $150 \mathrm{ml}$ selama 5 menit. Setelah itu sampel diangkat dan ditiriskan. Daya serap air dihitung dengan persamaan:

$$
\% \text { DSA }=\frac{\text { Berat mie matang }- \text { Berat mie segar }(g)}{\text { Berat mie segar }(g)}
$$

\section{Elastisitas (Ramlah, 1997)}

Sampel yang telah dimasak diambil seuntai lalu ditempatkan di atas penggaris dan diukur panjangnya sebagai panjang awal (PI), kemudian ditarik hingga putus dan diukur panjangnya sebagai panjang akhir (P2). Elastisitas dihitung dengan persamaan:

$$
\text { Daya Putus }=\frac{P 2-P 1}{P 1} \times 100 \%
$$

\section{Cooking Time (Chillo dkk., 2008)}

Pengukuran cooking time dilakukan dengan cara memasak mie pada air mendidih kemudian dilakuakn pengujian dengan cara setiap 30 detik mie diambil seuntai lalu diletakkan diantara 2 kaca transparan dan ditekan. Hal ini dilakukan berulang sampai titik putih ditengahnya menghilang yang menandakan mie sudah masak sempurna.

\section{Cooking loss Metode AACC 66-507 (Kang, dkk., 2017)}

Didihkan air sebanyak $150 \mathrm{ml}$, kemudian masukkan mie sebanyak 10 gram dan rebus selama 10 menit, lalu angkat dan ditiriskan selama 5 menit. sisa air perebusan dan air hasil penirisan dikumpulkan lalu dioven sampai berat konstan. Cooking loss dihitung dengan rumus :

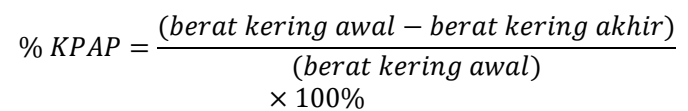

\section{Kadar Air (Metode Thermografimetri) (Sudarmaji, dkk., 1989)}

Sampel ditimbang sebanyak 2 gram dalam wadah yang telah diketahui beratnya, lalu sampel dikeringkan dalam oven dengan suhu $105^{\circ} \mathrm{C}$ selama 3-5 jam. Lalu sampel didinginkan dalam desikator 
selama 5 menit. Sampel dipanaskan kembali dalam oven selama 30 menit, didinginkan dalam eksikator dan ditimbang (diulangi sampai berat sampel konstan).

$$
\text { Kadar Air } \%=\frac{W o-W 1}{W o} \times 100 \%
$$

Keterangan :

Wo = Berat awal sampel $(\mathrm{g})$

$\mathrm{W}_{1} \quad=$ Berat kering sampel $(\mathrm{g})$

\section{Aktivitas Antioksidan Metode DPPH} (Andri dan Hersoelistyorini, 2013)

Uji aktivitas antioksidan dilakukan dengan menimbang DPPH sebanyak 0,15 g dilarutkan dalam $100 \mathrm{ml}$ etanol sehingga diperoleh konsentrasi $0,4 \mathrm{mM}$. Larutan dikocok hingga homogen dan diukur absorbansinya dengan spektrofotometer untuk memperoleh panjang gelombang maksimum. Panjang gelombang maksimum untuk larutan DPPH adalah $520 \mathrm{~nm}$. Larutan DPPH 0,4 nM diambil sebanyak 0,5 ml dimasukkan kedalam tabung reaksi dan ditambahkan $1 \mathrm{ml}$ sampel, lalu dihomogenkan menggunkan vortex hingga homogen hingga homogen lalu didiamkan sampai 30 menit pada suhu ruang dan diukur menggunakan spektrofotometer. Perhitungannya sebagai berikut:

$$
\% \text { Hambatan }=\frac{\text { abs blanko }- \text { abs sampel }}{\text { abs blanko }} \times 100 \%
$$

\section{Uji Organoleptik Tingkat Kesukaan (Bambang, dkk., 1988)}

Uji organoleptik dilakukan menggunakan metode hedonik (tingkat kesukaan). Uji ini dilakukan untuk mengetahui tingkat kesukaan panelis terhadap mie talas. Jumlah panelis yang digunakan dalam pengujian ini adalah 25 orang, dimana setiap panelis diminta untuk memberikan penilaian secara pribadi terhadap sampel yang disajikan. Parameter yang di uji yaitu, rasa, warna, aroma dan tekstur dengan skala penilaian (1) Sangat tidak suka; (2) Tidak suka; (3) Netral; (4) Suka; (5) Sangat suka.

\section{HASIL DAN PEMBAHASAN}

\section{Daya Serap Air (DSA)}

Daya serap air mie basah dari tepung komposit talas dan terigu dengan penambahan sari bayam merah berkisar antara $90,40 \%-114,88 \%$ dapat dilihat pada Gambar 1

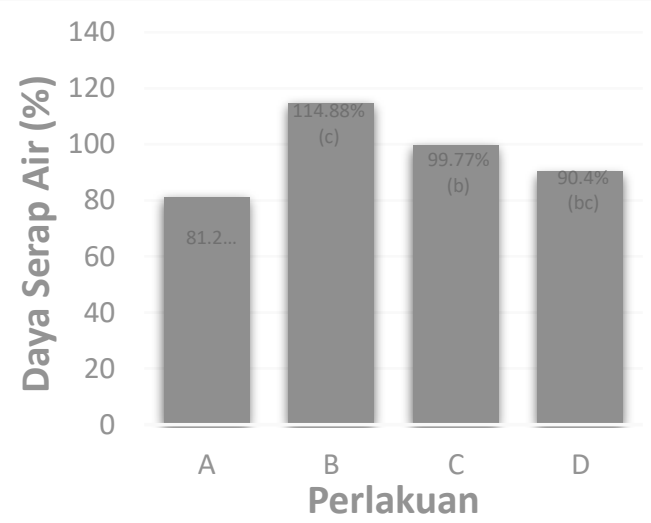

BNT $1 \%=17,58(*)$ Notasi yang berbeda menunjukkan adanya perbedaan nyata

Gambar 1. Nilai rata-rata daya serap air mie talas

Hasil uji sidik ragam menunjukkan bahwa perlakuan tepung komposit talas dan terigu terhadap mie basah memberikan pengaruh yang berbeda sangat nyata terhadap daya serap air. Daya serap air tertinggi diperoleh pada perlakuan B (80\% tepung talas : $20 \%$ tepung terigu), diikuti perlakuan $\mathrm{C}(70 \%$ tepung talas : $30 \%$ tepung terigu) dan perlakuan D (60\% tepung talas : $40 \%$ tepung terigu). Daya serap air terendah terdapat pada perlakuan A (kontrol 100\% tepung terigu). Daya serap air mie basah meningkat seiring dengan meningkatnya penambahan tepung talas. Hal ini diduga karena komponen karbohidrat utama dalam tepung talas adalah pati. Pati mempunyai kemampuan menyerap air. Selain itu, semakin banyak penambahan tepung talas akan membuat adonan mie basah lebih mudah dan lebih cepat 
dihomogenkan, sehingga daya serap airnya semakin tinggi. Hal tersebut sesuai dengan pendapat Tam, dkk (2004), bahwa jika suatu bahan mudah dan cepat dihomogenkan, maka akan cenderung memiliki kadar air yang tinggi.

\section{Elastisitas}

Elastisitas mie basah dari tepung komposit talas dan terigu dengan penambahan sari bayam merah berkisar antara $7,66 \%-15,87 \%$ dapat dilihat pada Gambar 2.

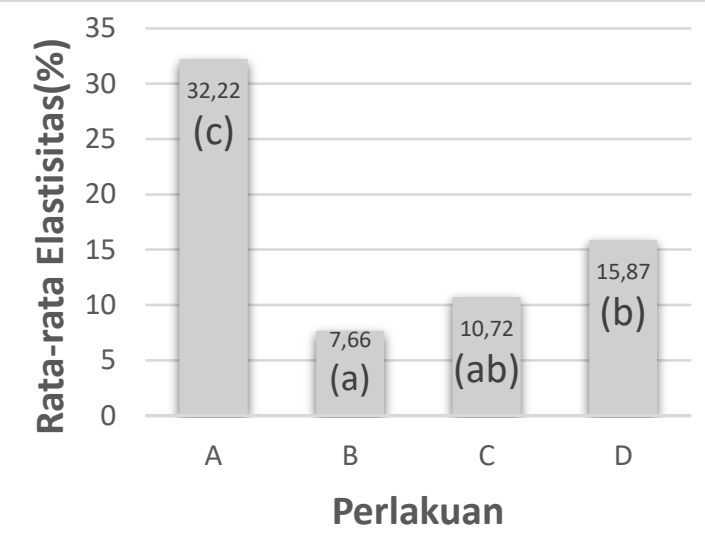

BNT $1 \%=5,77(*)$ Notasi yang berbeda menunjukkan adanya perbedaan yang nyata

Gambar 2. Nilai Rata-rata Elastisitas (\%) Mie Talas

Hasil uji sidik ragam menunjukkan bahwa perlakuan tepung komposit talas dan terigu terhadap mie basah memberikan pengaruh yang berbeda sangat nyata terhadap elastisitas. Elastisitas terendah terdapat pada perlakuan B (80\% tepung talas : $20 \%$ tepung terigu) dan tertinggi terdapat pada perlakuan D (60\% tepung talas : $40 \%$ tepung terigu) diikuti perlakuan $\mathrm{C}(70 \%$ tepung talas : $20 \%$ tepung terigu). Semakin sedikit penambahan tepung terigu semakin rendah elastisitas mie basah. Semakin banyak penambahan tepung talas pada mie basah, semakin rendah elastisitasnya. Hal ini karena kandungan gluten semakin menurun menyebabkan mie mudah patah. Selain hal tersebut, proses pemasakan juga akan berpengaruh terhadap gelatinisasi dan koagulasi protein yang dapat membentuk sifat elastisitas mie basah.

\section{Cooking Time}

Cooking time mie basah dari tepung komposit talas dan terigu dengan penambahan sari bayam merah berkisar antara 124,33 detik - 210,67 detik dapat dilihat pada Gambar 3 .

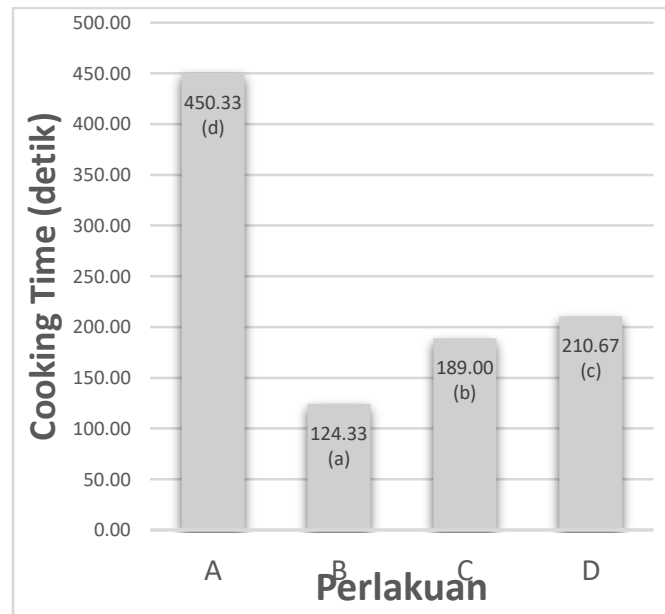

BNT $1 \%=6,84(*)$ Notasi yang berbeda menunjukkan adanya perbedaan yang nyata

Gambar 3. Nilai Rata-rata Cooking Time (detik) Mie Talas

Hasil uji sidik ragam menunjukkan adanya perbedaan sangat nyata dari perlakuan tepung komposit talas dan terigu terhadap cooking time mie basah. Cooking time paling cepat terdapat pada perlakuan B (80\% tepung talas : $20 \%$ tepung terigu) dan terlama terdapat pada perlakuan D (60\% tepung talas : $40 \%$ tepung terigu), diikuti perlakuan $\mathrm{C}(70 \%$ tepung talas : $30 \%$ tepung terigu). Semakin banyak jumlah tepung talas, cooking time mie basah semakin cepat. Hal ini sesuai dengan daya serap air mie basah yang semakin meningkat dengan meningkatnya penambahan tepung talas. Air yang tinggi masuk kedalam mie basah saat pemasakan menyebabkan cooking time akan semakin cepat. 


\section{Cooking Loss}

Cooking loss mie basah dari tepung komposit talas dan terigu dengan penambahan sari bayam merah berkisar antara 21,37 - 23,50 dapat dilihat pada Gambar 4.

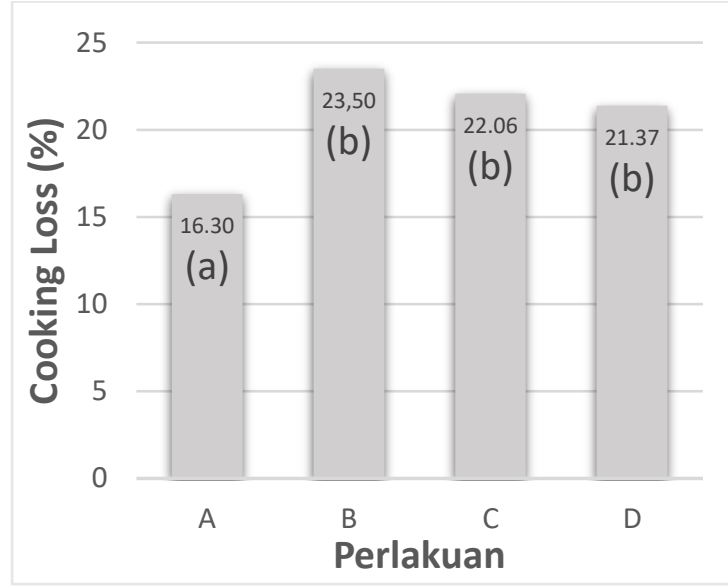

BNT $1 \%=2,59(*)$ Notasi yang berbeda menunjukkan adanya perbedaan yang nyata

Gambar 4. Nilai rata-rata Cooking Loss (\%) mie talas

Hasil uji sidik ragam menunjukkan adanya perbedaan nyata dari perlakuan tepung komposit talas dan terigu terhadap cooking loss mie basah. Cooking loss tertinggi terdapat pada perlakuan $\mathrm{B}(80 \%$ tepung talas : $20 \%$ tepung terigu) dan terendah terdapat pada perlakuan $\mathrm{D}(60 \%$ tepung talas : $40 \%$ tepung terigu), diikuti perlakuan $\mathrm{C}(70 \%$ tepung talas : $30 \%$ tepung terigu). Tingginya cooking loss dipengaruhi oleh kurangnya kandungan protein pada mie basah, karena protein berfungsi membentuk viskositas dan mengikat bahan sehingga tidak mudah larut dalam air. Kurangnya gluten akan membuat jaringan dalam mie basah melemah, sehingga sebagian padatannya mudah larut dalam air saat pemasakan. Mie yang baik memiliki cooking loss yang rendah (Engelen, 2015).

\section{Kadar Air}

Kadar air mie basah dari tepung komposit talas dan terigu dengan penambahan sari bayam merah berkisar antara 24,83- 25,43 dapat dilihat pada Gambar 5.

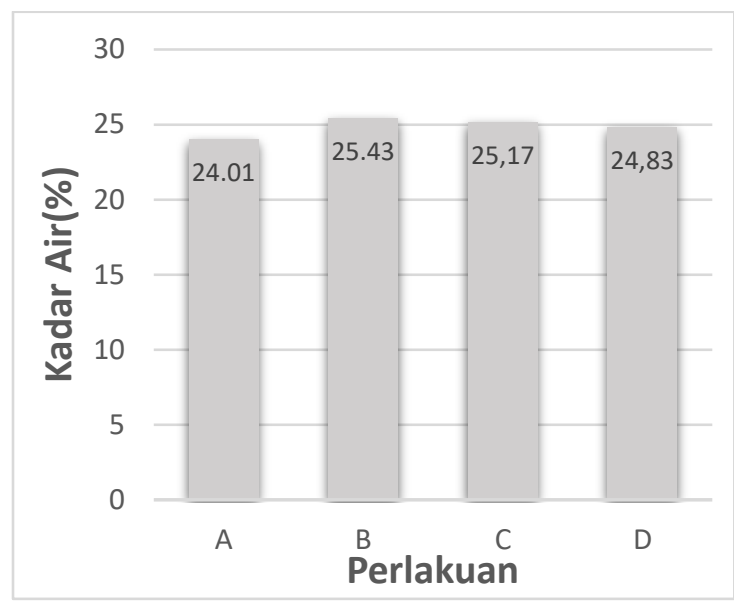

Gambar 5. Nilai rata-rata kadar air (\%) mie talas

Hasil uji sidik ragam menunjukkan tidak adanya perbedaan nyata perlakuan terhadap kadar air mie basah. Kadar air tertinggi terdapat pada perlakuan B $(80 \%$ tepung talas : $20 \%$ tepung terigu) dan terendah terdapat pada perlakuan D $(24,83)$. Tingginya kadar air pada mie basah diduga karena adanya kandungan serat dari sari bayam merah dimana serat mempunyai sifat yang hidrokoloid yang mampu mengikat air. Selain itu, pati yang terdapat pada bahan cenderung suka air (hidrofil), karena jumlah gugus hidrofil dalam molekul pati sangat besar sehingga kemampuan dalam menyerap air juga besar yang menyebabkan air berada dalam butir-butir pati dan tidak dapat bergerak bebas (Winarno, 2002).

\section{Aktivitas Antioksidan}

Gambar 6 menunjukkan bahwa aktivitas antioksidan mie dari tepung komposit talas dan terigu dengan penambahan sari bayam merah tergolong lemah dilihat dari nilai $\mathrm{IC}_{50} \mathrm{yg}$ lebih besar dari $200 \mu \mathrm{g} / \mathrm{ml} . \quad \mathrm{IC}_{50}$ didapat dari penyelesaian persamaan regresi $\mathrm{Y}$ $=0,0151 \mathrm{X}+46,69$ dimana $\mathrm{Y}$ adalah persentasi penghambatan $50 \%(0,5)$ dan $X$ 
konsentrasi aktivitas antioksidan. Molyneux (2004) dalam Tristantini, dkk (2016), mengatakan bahwa semakin rendah nilai $\mathrm{IC}_{50}$ maka semakin kuat aktivitas antioksidannya.Jenis antioksidan pada mie basah yang diperoleh dari sari bayam merah adalah betakaroten dan flavonoid.

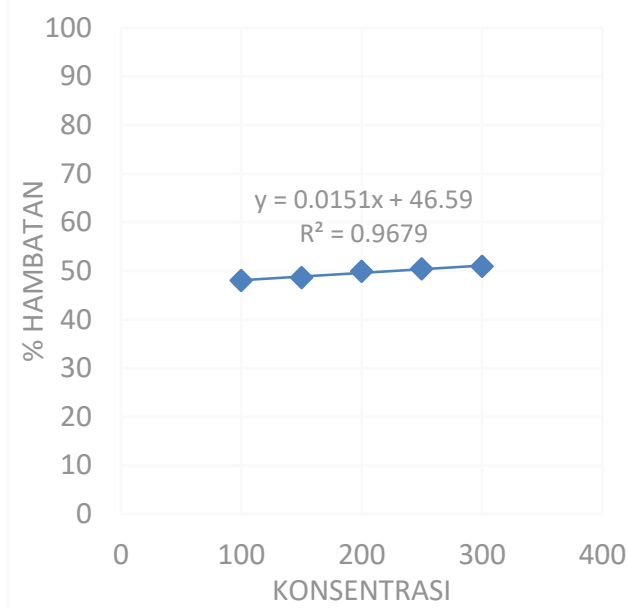

Gambar 6. Grafik hubungan antara konsentrasi aktivitas antioksidan dengan persen penghambatan untuk mendapat nilai $\mathrm{IC}_{50}$.

\section{Tingkat kesukaan}

\section{Warna}

Tingkat kesukaan terhadap warna mie basah berbahan baku tepung talas dan tepung terigu dengan penambahan sari bayam merah berkisar antara 3,40\% $3,56 \%$ dengan tingkat penilaian dari sangat tidak suka sampai sangat suka.

Hasil dari uji organoleptik terhadap warna dapat dilihat pada Gambar 8. Hasil uji sidik ragam menunjukkan tidak adanya pengaruh dari tingkat kesukaan panelis terhadap warna mie basah yang dihasilkan. Nilai rata-rata warna mie basah yang disukai tertinggi terdapat pada perlakuan B (80\% tepung talas : $20 \%$ tepung terigu) dan terendah pada perlakuan D $(60 \%$ tepung talas :40\% tepung terigu). Tidak adanya pengaruh terhadap organoleptik warna mie basah disebabkan jumlah penambahan sari bayam pada masing-masing perlakuan sama, sehingga warna yang dihasilkan pada setiap perlakuan tidak berbeda nyata. Warna pada perlakuan mie basah cukup disukai panelis karena warna yang dihasilkan merah keunguan yang berasal dari warna sari bayam yang ditambahkan pada mie basah. Warna tersebut dihasilkan oleh pigmen antosianin yang terdapat pada bayam merah. Antosianin pada bayam merah berperan sebagai antioksidan yang berfungsi untuk mencegah pembentukan radikal bebas (Lingga, 2010).

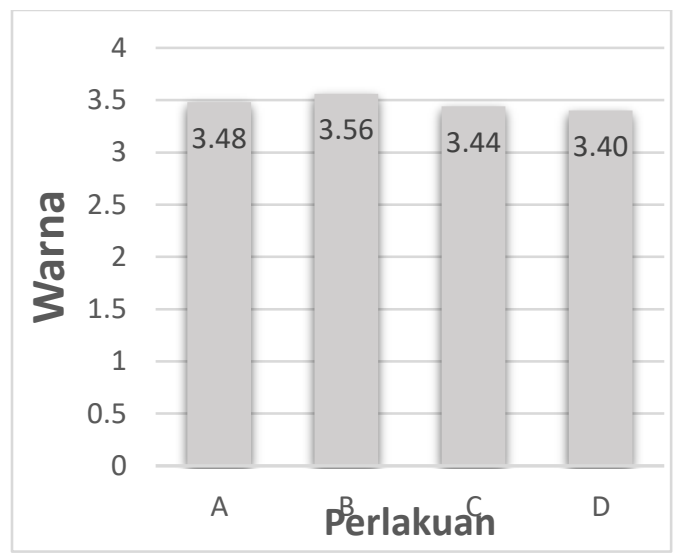

Gambar 8. Tingkat kesukaan terhadap warna

\section{Aroma}

Tingkat kesukaan terhadap warna mie basah berbahan baku tepung talas dan tepung terigu dengan penambahan sari bayam merah berkisar antara 2,28\% $2,96 \%$ dengan tingkat penilaian dari sangat tidak suka sampai sangat suka. Hasil dari uji organoleptik terhadap warna dapat dilihat pada Gambar 9.

Hasil uji sidik ragam menunjukkan tidak adanya pengaruh tingkat kesukaan panelis dari perlakuan (tepung talas dan tepung terigu) terhadap aroma mie basah. Tingkat kesukaan terhadap aroma terendah terdapat pada perlakuan $\mathrm{C}(70 \%$ tepung talas : $30 \%$ tepung terigu) nilai 2,80 dan diikuti perlakuan $\mathrm{B}$ dan $\mathrm{C}$ de ngan nilai 24,83. Panelis cenderung kurang menyukai aroma mie basah yang besar proporsi tepung talasnya karena aroma talas yang tajam. Hal ini juga 
disebabkan panelis lebih terbiasa mengonsumsi mie basah dengan bahan baku tepung terigu.

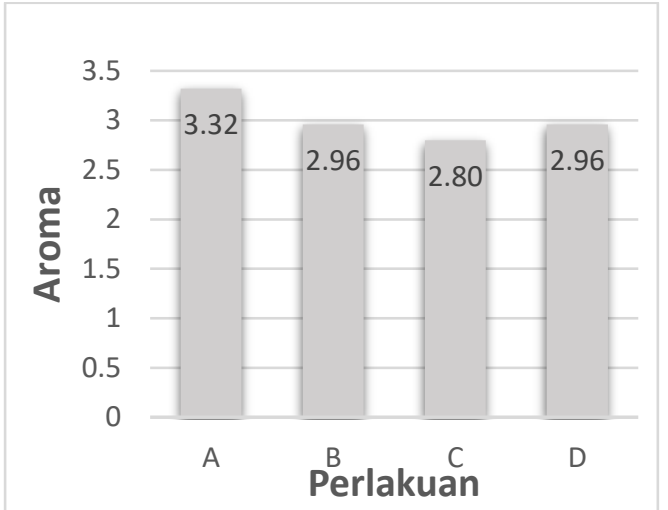

Gambar 9. Tingkat kesukaan terhadap aroma

\section{Rasa}

Hasil uji organoleptik rasa mie basah dari tepung talas dan tepung terigu dengan penambahan sari bayam merah berkisar antara 2,96 - 2,24 dengan tingkat penilaian dari suka sampai sangat suka sampai netral. Nilai tingkat kesukaan terhadap aroma dapat dilihat pada Gambar 10.

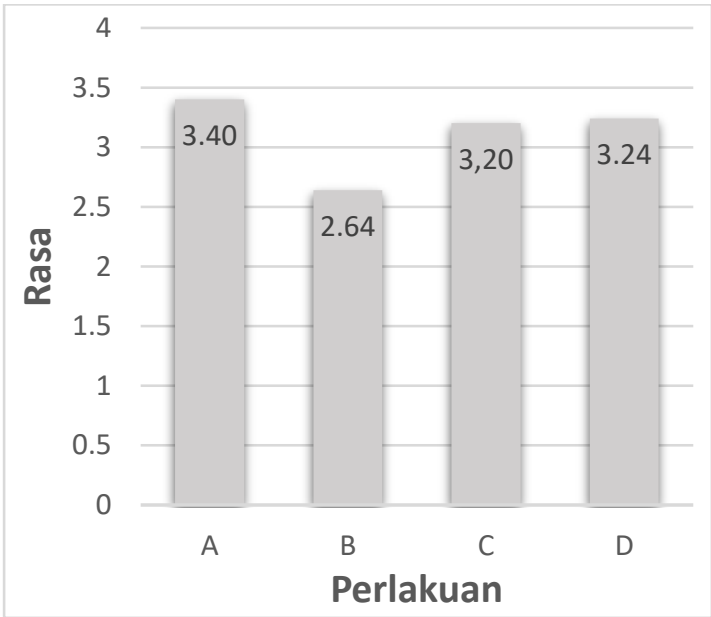

BNT $1 \%=0,47(*)$ Notasi yang berbeda menunjukkan adanya perbedaan yang nyata

Gambar 10. Tingkat kesukaan terhadap rasa

Hasil uji organoleptik menunjukkan adanya perbedaan tingkat kesukaan terhadap rasa pada perlakuan mie basah. Rasa yang paling banyak disukai terdapat pada sampel $\mathrm{D}(80 \%$ tepung talas : $20 \%$ tepung terigu) dengan nilai $25,50 \%$. Hal ini diduga karena kebiasaan mengonsumsi mie dari tepung terigu pada umumnya sehingga rasa mie basah dengan penambahan tepung talas kurang disukai.

\section{Tekstur}

Hasil uji organoleptik tekstur mie basah dari tepung talas dan tepung terigu dengan penambahan sari bayam merah berkisar antara 2,96 - 3,36 dengan tingkat penilaian dari sangat tidak suka sampai sangat suka. Hasil dari uji organoleptik tingkat kesukaan terhadap tekstur dapat dilihat pada Gambar 11.

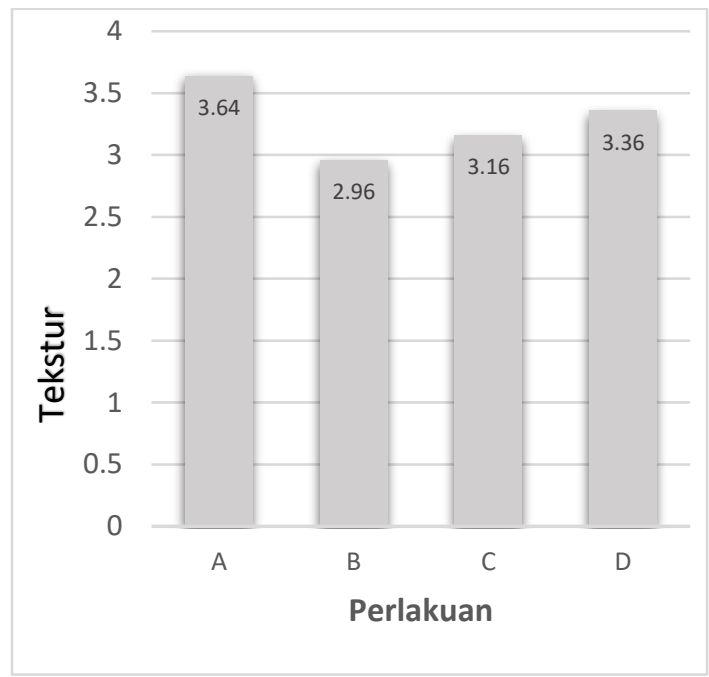

BNT 5\% $=0,49(*)$ Notasi yang berbeda menunjukkan adanya perbedaan yang nyata

Gambar 11. Tingkat kesukaan terhadap tekstur

Hasil uji sidik ragam menunjukkan adanya pengaruh tingkat kesukaan panelis dari perlakuan tepung talas dan tepung terigu terhadap tekstur mie basah. Tekstur yang paling banyak disukai terdapat pada perlakuan D (60\% tepung talas : $40 \%$ tepung terigu) dengan nilai 3,36. Tekstur mie basah dengan proporsi tepung talas yang besar cenderung kurang kenyal dan lunak/mudah patah, sehingga panelis cenderung kurang menyukai. Hal ini disebabkan tepung talas tidak mengandung gluten. 
Secara keseluruhan, tingkat pada table 1. kesukaan terhadap mie talas dapat dilihat

Tabel 1. Rata-rata keseluruhan tingkat kesukaan terhadap mie talas

\begin{tabular}{cccccc}
\hline Sampel & Warna & Aroma & Rasa & Tekstur & Rata-rata \\
\hline A & 3,48 & 3,32 & 3,40 & 3,64 & 3,46 \\
B & 3,56 & 2,96 & 2,64 & 2,96 & 3,03 \\
C & 3,44 & 2,80 & 3,20 & 3,16 & 3,15 \\
D & 3,40 & 2,96 & 3,24 & 3,36 & 3,24 \\
\hline
\end{tabular}

Berdasarkan uji organoleptik tingkat kesukaan, perlakuan yang paling disukai adalah perlakuan pada gambar 12 yang garisnya berada paling luar. Garis paling luar adalah perlakuan A $(100 \%$ tepung terigu) yaitu kontrol, lalu diikuti sampel D (60\% tepung talas : $40 \%$ tepung terigu).

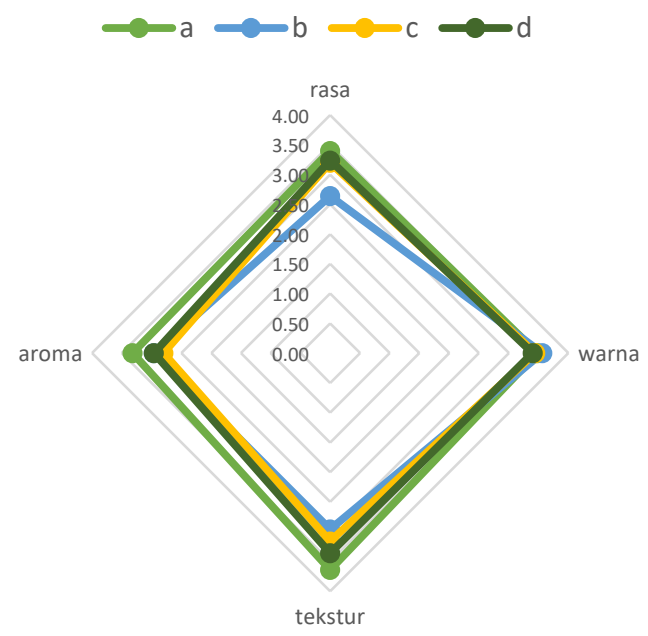

Gambar 7. Tingkat Penerimaan Panelis Secara Keseluruhan

\section{KESIMPULAN}

Semakin besar proporsi tepung talas, makin besar daya serap air dan cooking loss mie talas. Nilai tertinggi untuk daya serap air dan cooking loss terdapat pada perlakuan $\mathrm{B}(80 \%$ tepung talas : $20 \%$ tepung terigu) dan terendah terdapat pada perlakuan A (kontrol 100\% tepung terigu). Namun sebaliknya untuk elastisitas dan cooking time semakin rendah pada perlakuan B dan semakin tinggi untuk perlakuan A. Tingkat penerimaan panelis terhadap rasa dan tekstur mie talas menurun seiring dengan semakin besarnya proporsi tepung talas dengan taraf penerimaan netral. Namun secara keseluruhan aspek organoleptik yang diuji tidak jauh berbeda dengan mie basah dari tepung terigu. Sedangkan aktivitas antioksidannya tergolong lemah, yaitu dengan nilai $\mathrm{IC}_{50} 225,82 \mu \mathrm{g} / \mathrm{ml}$. Mie talas dengan hasil kadar air yaitu dibawah $35 \%$, kadar abu dibawah 3\% yaitu $(1,85 \%)$ dan kadar protein $(5,02 \%)$ maksimum $8 \%$ memenuhi stardar berdasarkan syarat mutu mie basah dalam SNI 2046-90.

\section{DAFTAR PUSTAKA}

Andri, D. dan Hersoelistyorini, W. 2013. Aktivitas Antioksidan dan Sifat Organoleptik dari Daun Sirsak (Anoma muricate Linn). Jurusan Teknologi Pangan Fakultas Pertanian Universitas Muhammadiyah Semarang. Jurnal Pangan dan Gizi Vol. 4 No. 7.

Bambang, Kartika, Pudji, H., Wahyu, S. 1988. Pedoman Uji Indrawi Bahan Pangan. Yogyakarta: Universitas Gajah Mada.

Chillo, S., J. Laverse, PM Falcone, A. Protopapa dan MA Del Nobile. 2008. Pengaruh dari penambahan tepung soba dan gandum durum dedak pada kualitas spageti. Jurnal Cereal Sci. 47 (2): 144-152. 
Departemen Kesehatan RI. 2009. Daftar Komposisi Bahan Makanan. Jakarta : Bhratara Karya Asara.

Engelen, A. 2015 Optimasi Proses da Formula pada Karakteristik Kelengketan Mi Sagu, Jtech. 01:40-47.

Gumilang, R., S. Bambang, Y. Rini. 2015. Uji Karakteristik Mie Instan Berbahan Baku Tepung Terigu dengan Substitusi Tepung Talas (Colocasia Esculenta (L.) Schott). Jurnal Bioproses Komoditas Tropis Vol. 3 No. 2.

Goldberg. 1994. Introduction, in Functional Foods; Designer Foods, Pharmafoods, Nutraceuticals, Chapman and Hall, London.

Kang, J., Jung, L., Moonkyeung, C., Yongik, J., Dongchil, C., Yoon, H.C., Misook, K., Yoonhwa, J., dan Youngseung, L. 2017. Physicochemical and Textura Properties of Noodles Prepared from Different Potato Varieties.

Lingga, L. 2010. Cerdas Memilih Sayuran, PT. Agro Media Pustaka, Jakarta.

Murniyati, Subaryono, H. Irma. 2010. Pengolahan Mie yang Difortifikasi dengan Ikan dan Rumput Laut sebagai Sumber Protein, Serat Kasar, dan Iodium. Jurnal Pascapanen dan Bioteknologi Kelautan dan Perikanan Vol. 5 No. 1.

Permatasari, S., Sry, W., Suciyati. 2009. Pengaruh Rasio Tepung Talas dan Tepung Terigu Terhadap Sifat Kimia dan Organoleptik Mie Basah. Prosiding Seminar Nasional Fakultas Teknologi Pertanian Universitas Udayana.

Pratiwi, A., Ansharullah, Abdu, R.B. 2017. Pengaruh Substitusi Tepung Talas (Colocasia esculenta L. Schoott) Terhadap Nilai Sensorik dan Nilai Gizi Roti Manis. Jurnal Sains dan Teknologi Pangan (JSTP) Vol. 2 No. 4: 749-758.

Ramlah. 1997. Sifat Fisik Adonan Mie dan Beberapa Jenis Gandum dengan Penambahan Kansui, Telur, dan Ubi Kayu. Yogyakarta: Universitas Gajah Mada.

Rahmawati, W. A. K. Yovita, A. Nita. 2012. Karakterisasi Pati Talas (Colocasia esculenta (L.) Schoot) sebagai Alternatif Sumber Pati Industri Indonesia. Jurnal Teknologi Kimia dan Industri, Vol. 1 No. 1, Tahun 2012, Halaman 347-351.

Rufaizah, U. 2011. Pemanfaatan Tepung Sorgum (Sorghum bocolor L. Moench) pada Pembuatan Snack Bar Tinggi Serat Pangan dan Sumber Zat Besi untuk Remaja Putri. Departemen Gizi Masyarakat. Fakultas Ekologi Manusia. Institut Pertanian Bogor.

Sudarmaji, S, dkk. 1989. Analisa Bahan Makanan dan Pertanian. Penerbit Liberty: Yogyakarta.

Suyanti. 2008. Membuat Mie Sehat Bergizi dan Bebas Pengawet. Penebar Swadaya. Jakarta.

Suhaeni, N., 2007. Petunjuk Praktis Menanam Talas. Jembar Publishing: Bandung.

Setyarini, E. 2013. Pengaruh Perbandingan Tepung Terigu Dengan Tepung Pisang Ambon Terhadap Elastisitas dan Daya Terima Mie Basah. Tidak Diterbitkan. Fakultas Ilmu Kesehatan Universitas Muhammadyah: Surakarta.

Tam L. M., H. Corke, W.T. Tan, J. Li, dan L. S. Collado. 2004. Production of Bihon-Type Noodles from Maize Starch Differing in Amylosa Content. J Cereal Chem. 81(4):475-480. 
Tristantini, D., I. Alifah, T. P. Bhayangkara, G. Jason. 2016. Pengujian Aktivitas Antioksidan Menggunakan Metode DPPH pada Daun Tanjung (Mimusops elengi L). Prosiding Seminar Nasional Program Studi Teknik Kimia, Universitas Indonesia Depok Jawa Barat, ISSN 1693-4393.

Winarno, F.G. 1997. Kimia Pangan dan Gizi. PT. Gramedia Pustaka Utama. Jakarta.

Widyaningsih, T.W. dan Murtini, E.S. 2006. Alternatif Pengganti Formalin pada Produk Pangan. Trubus Agirasana, Surabaya.

Wiyasihati, S.I, W. W. Kristanti. 2016. Potensi Bayam Merah (Amaranthus tricolor L.) sebagai Antioksidan pada Toksisitas Timbal yang Diinduksi pada Mencit. Departemen Ilmu Faal Fakultas Kedokteran Universitas Airlangga Surabaya, MKB, Vol. 48 No. 2. 